\title{
Mineral composition of Cola parchycarpa (K. Schum) Arils and Seeds
}

\author{
${ }^{1}$ Nwiisuator D. ${ }^{*}$ E. Oddo ${ }^{1}$, E.A., Emerhi1, Owuno, $F^{2}$ and P.Sangha ${ }^{1}$ \\ ${ }^{1}$ Department of Forestry and Environment, \\ ${ }^{2}$ Department of Food Science and Technology, \\ Rivers State University of Science and Technology, Nkpolu, Port Harcourt, Nigeria \\ P.M.B. 5080
}

\begin{abstract}
This investigated the minerals and anti-nutritional composition of Cola parchycarpa fruits (edible parts arils and seeds). Completely randomized design (CRD) was the experimental design with two treatments and three replicates. Results showed that there was no significant difference $(P \geq 0.05)$ between mineral compositions of the arils and seeds. Proximate contents was higher in arils and lower in seeds: crude protein- $6.83 \pm 1.58 \%$ and $3.67 \pm 1.58 \%$; moisture content$(10.14 \pm 2.03 \%)$ and $6.08 \pm 2.03 \%$, ash $-(3.87 \pm 0.69) \%$ and $(2.48 \pm 0.69) \%$, crude fibre- $(19.12 \pm 6.17)$ $\%$ and $(6.77 \pm 6.17) \%$, while a reverse trend in crude fat and carbohydrate $0 \%$ and $4.76 \pm 2.38 \%$, $(60.04 \pm 8.10)$ and $(76.24 \pm 8.10) \%$ respectively. Similarly, the arils recorded higher minerals than in the seeds-Sodium $(53.50 \pm 0.80) \mathrm{mg} / \mathrm{kg}$ and $(51.9 \pm 0.80) \mathrm{mg} / \mathrm{kg}$, Calcium- $(17.8 \pm 2.75) \mathrm{mg} / \mathrm{kg}$ and $(12.3 \pm 2.75) \mathrm{mg} / \mathrm{kg}$, traces of Copper $(0.15 \pm 0.07) \mathrm{mg} / \mathrm{kg}$, Zinc- $(0.55 \pm 0.28)$, no Zinc and Copper in the arils. Seeds contained high Potassium $(5626.65 \pm 1984.3) \mathrm{mg} / \mathrm{kg}$ while the arils had $(1658.05+1984.3) \mathrm{mg} / \mathrm{kg}$, seeds had higher Magnesium $(586.75 \pm 258.70) \mathrm{mg} / \mathrm{kg}$ and aril $(69.35 \pm 69.35) \mathrm{mg} / \mathrm{kg}$. Seeds contained no iron, zinc, copper, and lead. Arils contained antinutritional factor (tannin) $(0.1 \pm 0.37) \%$, seed had $0.84 \pm 0.37 \%$. Species contains key dietary minerals that not only relish but will improve mineral intake from nature that can be used as supplements to replace some vital minerals of the body. Amino acids of the species should be studied.
\end{abstract}

Keywords: Aril, Seed, Mineral Composition, Dietary

\section{INTRODUCTION}

Cola pachycarpa of Sterculiaceae family, it is a tropical species found in lowland forest of some West African countries- including Cameroun, Gabon and Nigeria (Keay et al., 1964). The mature tree can attain a height of $20-60 \mathrm{ft}(6-18 \mathrm{~m})$, girth up to $3 \mathrm{ft}$ $(0.9 \mathrm{~m})$, with very few or no branches; leaves crowded at the top of stem. Bark varying from grey to dark brown; slash cream, streak with yellow-brown lines. It flowers from January to June borne in clusters on the stem below the leaves and extending right down to the base; stalks 0.7-2 inches, reddish-purple; calyx cup-shape, 0.5-1.4 in. long, pale red, white; anthers in whorl. Fruits (July-Nov.) composed of up to 6 large, boat-shaped, shiny, pink or red, glabrous carpels; each carpel 4.8-8 in. long, 2.4 in. broad with a short stalk, a pronounced beak and 3 rather knobbly longitudinal ridges; seeds few, very large, each enclosed in a thick waxy white aril. (Keay et al., 1964).
The urgency of the world's food problems has thrown a challenge to foresters' and nutritionists alike to investigate the possibility of utilizing some woody plant species as additional sources of nutrient. Since these woody plant species are consumed by both wild and domestic animals alike, it is true that they may be contributing some nutrients to the nutritional requirements of wild, domestic animals and so are safe to be eaten by man. Oregbeme (2005) noted the propagation and cultivation of economic nontimber forest products and fruit trees are a sure possibility for poverty alleviation in rural communities in Edo state. Jimoh and Haruna (2007) also reported that forest products (NTFPs) contribute significantly to household food security and income around Onigambari forest reserve in Oyo state.

Tehoundjan et al., (2002) asserted that wide range of edible products available in the wild fruit tree include among other nuts and seeds used as food supplement. The fruits of the species are abundant in villages, markets, along major high ways in the state, 
and apart from scientific curiosity the need to study nutritive content of the species is imperative.

In several attempts to assess quantitative nutrient intake by man, emphasis has always been placed on orthodox food with less regard to natural food from the forest. The contribution of these woody plants in the dietary needs and nutrition requirements of local species have been overlooked. It has been observed that seeds of Afzelia bella and Parkia clappertonians are used as condiments in stews in several parts of Nigeria. Studies indicated that Afzellia africana, Azadirachta indica, Monodora tenuiflania and Pterocarpus mildraedii are being employed by natives for medicinal purposes. Results from analyses of these seeds indicated that some seeds and nuts showed considerable promise as protein sources. Since protein is used as an index of nutritional values, it is therefore, important that the nutrient composition of these woody plant species be determined to enable the assessment of their potential contribution to dietary needs of man.

The diet of an average Nigerian is deficient in several nutrients notably protein. The country has the varied and abundant potential materials of food which if adequately utilized may meet some of the country's basic dietary requirements. In recent years, a lot of money has been spent in importing vegetable oil and protein foods, it is therefore important that the nutrient composition of these woody plant species be determined to enable the assessment of their potential contribution to dietary needs of man (Ogbonna, 1983).Hence, there is need to examine the nutritive qualities of indigenous species like Cola pachycarpa to augment the lean supply. Therefore, the objective was to determine the proximate, mineral and anti-nutritional compositions of the seeds and fruits of the species.

\section{METHODOLOGY}

Samples were collected from villages in Ogoni land. The cover was removed from the edible part of the fruit remaining the aril and the seed there in. Ten samples (arils-edible parts +seeds) were sun dried at temperature of between $27{ }^{\circ} \mathrm{C}$ and $30{ }^{\circ} \mathrm{C}$ and analyzed for chemical and anti-nutritional factor. The samples were taken to the Department of Food Science and Technology, Nkpolu, Port Harcourt and University of Port Harcourt for analysis.

Proximate analysis: Samples were analyzed for moisture content, crude fibre, ash, crude fat, crude protein, carbohydrate, according to the procedure of AOAC (1990).

Mineral Analysis: The mineral composition of the species (edible portion + seed), samples were ashed at $550{ }^{\circ} \mathrm{C}$ for 48 hours; the ash from each was digested with $10 \mathrm{ml}$ of $10 \% \mathrm{HCL}$ in a beaker. The mixture was filtered and the filtrate of $50 \mathrm{ml}$ in the standard flask with deionized water used in standardization of solution. The minerals were determined using Atomic Absorption Spectrophotometer (AAS). The following minerals were assessed: - Sodium (Na), Potassium (K), Magnesium (Mg), Calcium (Ca), Iron (Fe), Zinc (Zn), Lead $(\mathrm{Pb})$, and Copper $(\mathrm{Cu})$.

Anti-nutritional Analysis: The anti-nutritional analysis of tannin was carried out on both the edible part called the aril and seed.

Experimental Design: The Completely Randomized Design (CRD) was used with three (2) treatments and three (3) replicates. The data were analyzed using one-way analysis of variance (ANOVA), means and standard error using MS excel and SPSS analytic packages.

\section{RESULTS AND DISCUSSION}

Proximate content: There was no significant difference at $\mathrm{P} \geq 0.05$ (Table 2) between mineral composition of the arils and seeds. Though, there were a few differences between the seeds and arils: results indicated that samples fruit (arils and seeds) had crude protein of $6.83 \pm 1.58 \%$ in arils and $3.67 \pm 1.58 \%$ in seeds, high fibre $(19.12 \pm 6.17)$ in arils, low fibre content $(6.77 \pm 6.17) \%$ in seeds (Table 1 and Figure 1). The high fibre content of the aril (edible portion) supports the recommendation of fruit to the sick because aids digestion. The low fibre content of the seeds is an indication that they can be digested more easily than the arils (edible parts) if the former were edible. 

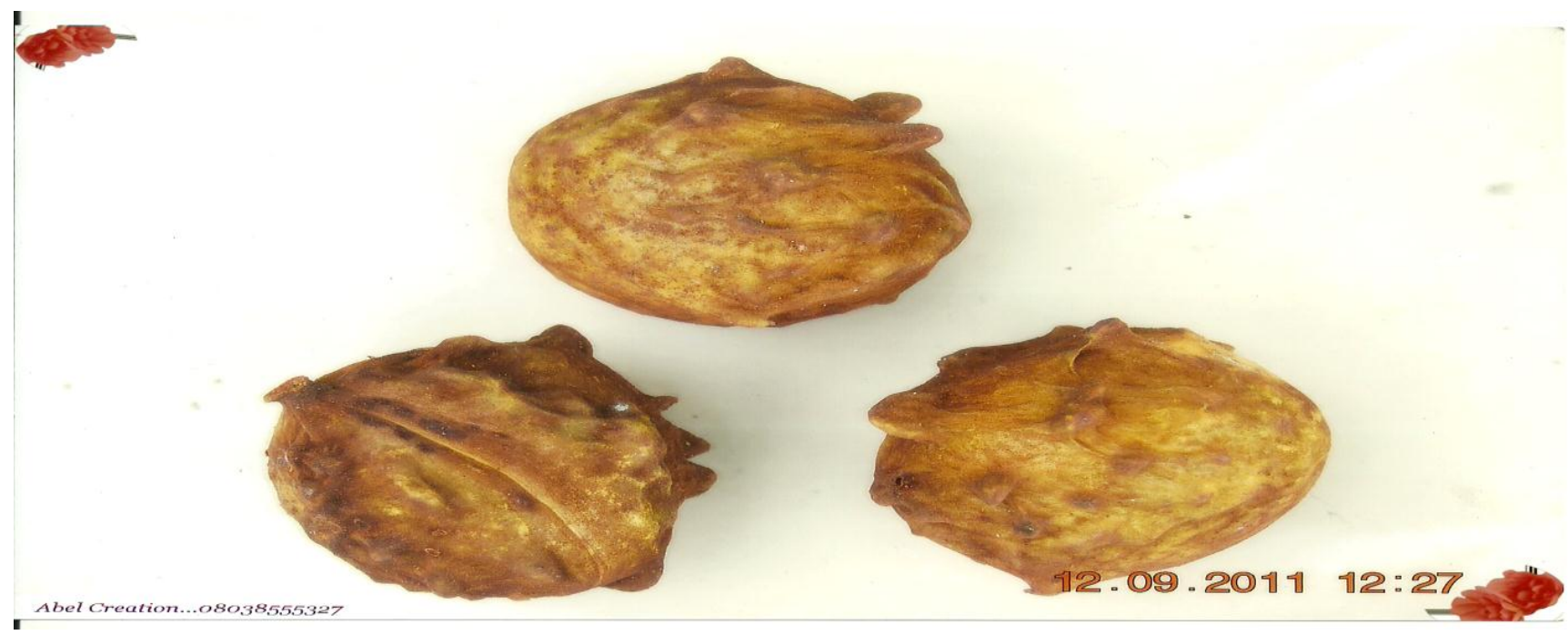
I

Fig 1: Samples (Fruits) of Cola parchycarpa

The moisture content was higher $(10.14 \pm 2.03) \%$ in arils than in the seed $(6.08 \pm 2.03) \%$ while the reverse was the case in crude fat as seed had $4.76 \pm 2.38 \%$ and 0 in aril. Similarly, high carbohydrate $(76.24 \pm 8.10) \%$ was observed in seed and $60.04 \pm 8.10) \%$ in aril, which indicate that the species can be a dietary source of energy, conversely, the species contains ash $(3.87 \pm 0.69) \%$ in arils and $(2.48 \pm 0.69) \%$ in seeds (Table 1$)$. The more protein content in the arils gives an insight into the rush for the species in Ogoni land and other parts of Nigeria. The protein levels in aril is high which shows it can be an alternative and natural source of protein to humans while the seeds that contain low protein and other mineral constituents could be used in food manufacturing industries.

This high protein of the species indicated that it contains high nutritional values and has a great potential towards contribution to dietary needs of man.

Table 1: Proximate and mineral Composition of fruits and seeds (Mean +SEM)

\begin{tabular}{|l|c|c|c|}
\hline & Aril & Seed & Std. Error \\
\hline Moisture content (\%) & 10.14 & 6.08 & $2.03^{*}$ \\
\hline Ash (\%) & 3.87 & 2.48 & $0.695^{*}$ \\
\hline Crude Fat (\%) & 0 & 4.76 & $2.38^{*}$ \\
\hline Crude Protein (\%) & 6.83 & 3.67 & $1.58^{*}$ \\
\hline Carbohydrate (\%) & 60.04 & 76.24 & $8.1^{\text {NS }}$ \\
\hline Crude Fibre (\%) & 19.12 & 6.77 & $6.175^{*}$ \\
\hline Potassium (mg/kg) & 1658.05 & 5626.65 & $1984.3^{\text {NS }}$ \\
\hline Sodium (mg/kg) & 53.5 & 51.9 & $0.80^{\text {NS }}$ \\
\hline Calcium $(\mathrm{mg} / \mathrm{kg})$ & 17.8 & 12.3 & $2.75^{*}$ \\
\hline Magnesium $(\mathrm{mg} / \mathrm{kg})$ & 69.35 & 586.75 & $258.70^{\mathrm{NS}}$ \\
\hline Lead $(\mathrm{mg} / \mathrm{kg})$ & 0 & 0 & 0 \\
\hline Copper $(\mathrm{mg} / \mathrm{kg})$ & 0.15 & 0 & $0.075^{*}$ \\
\hline Zinc $(\mathrm{mg} / \mathrm{kg})$ & 0.55 & 0 & $0.28^{*}$ \\
\hline Iron $(\mathrm{mg} / \mathrm{kg})$ & 0 & 0 & 0 \\
\hline Tannins $(\%)$ & 0.1 & 0.84 & $0.37^{*}$ \\
\hline
\end{tabular}

${ }^{*}$ Significant at $\mathrm{P} \leq 0.05$

NS- Not significant $(P \geq 0.05)$ 
Table 2: Composition of the arils and seeds Cola pachycarpa

\begin{tabular}{|l|c|c|}
\hline$t-T e s t:$ Composition of arils \& seeds & \\
\hline & & Fruit \\
\hline Mean & 199.9444 & 697.6044 \\
\hline Variance & 299664.8 & 3453305 \\
\hline Observations & 9 & 9 \\
\hline Pooled Variance & 1876485 & \\
\hline Hypothesized Mean Difference & 0 & \\
\hline$d f$ & 16 & \\
\hline$t$ Stat & -0.77067 & \\
\hline$P(T<=t)$ one-tail & 0.226068 & \\
\hline$t$ Critical one-tail & 1.745884 & \\
\hline$P(T<=t)$ two-tail & 0.452135 & \\
\hline$t$ Critical two-tail & 2.119905 & \\
\hline
\end{tabular}

Ho rejected: since $F_{c a l}$ is less than $F_{\text {tab }}$ : there is no significant difference (P $\left.\geq 0.05\right)$

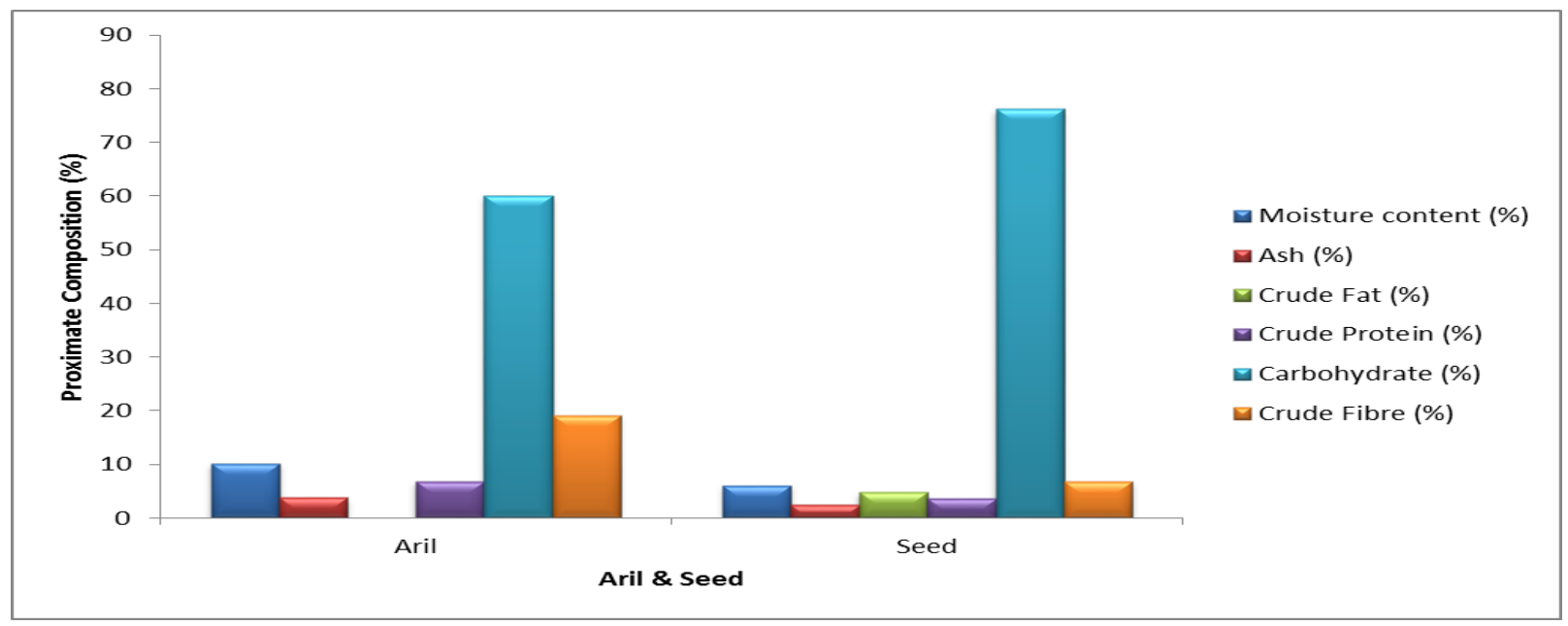

Fig 1: Proximate composition of seeds and arils of Cola pachycarp

Mineral composition: The high contents of minerals in the aril especially Sodium $(53.5 \pm 0.80) \mathrm{mg} / \mathrm{kg}$, calcium $(17.8 \pm 2.75) \mathrm{mg} / \mathrm{kg}$ and trace of Copper and Zinc (Table 4.1) also indicated that the aril can be used as dietary mineral supplement particularly where strengthening foods are needed. The arils contain Magnesium (69.35 \pm 258.70$) \mathrm{mg} / \mathrm{kg}$ and Potassium (1658.05 \pm 1984.3$) \mathrm{mg} / \mathrm{kg}$. George and Pamplona-Roger, (2010) reported that oranges contain $10 \mathrm{mg} / \mathrm{kg}$ of Magnesium $(\mathrm{Mg})$ and $181 \mathrm{mg} / \mathrm{kg}$ Potassium (K). From this finding, the species contains several times more of $\mathrm{Mg}$ and $\mathrm{K}$ than oranges. The seeds surprisingly contained high minerals like Potassium (5626.65 \pm 1984.30$) \mathrm{mg} / \mathrm{kg}$; seeds had higher Magnesium (586.75 258.70$) \mathrm{mg} / \mathrm{kg}$ (Table 4.1). The seeds contained no iron, zinc, copper, and lead but arils contain traces of Copper $(0.15 \pm 0.075) \mathrm{mg} / \mathrm{kg}$ and Zinc $(0.55 \pm 0.28) \mathrm{mg} / \mathrm{kg}$. The seeds surprisingly contained high minerals like Potassium $(5626.65 \mathrm{mg} / \mathrm{kg}$ ) while the arils had just $1658.05 \mathrm{mg} / \mathrm{kg}$, seeds had higher Magnesium $(586.75 \mathrm{mg} / \mathrm{kg})$ and aril recorded $69.35 \mathrm{mg} / \mathrm{kg}$. The protein, ash and carbohydrate contents of this species showed promise as a dietary supplement. This agrees with Ogbonna, (1983) that some seeds and nuts showed considerable promise as protein 
sources which is an index of nutritional values and Afolabi (2008) that there are vast numbers of edible plants products garnered from forests, include seeds and nuts, leaves, fruits, roots and tubers, fungi and salt, collectively they add diversity and flavor to the diet while providing protein, energy, vitamins and essential minerals.

Anti-nutritional factor: Anti-nutritional factor -tannin observed in both the seeds $(0.84 \mathrm{mg} / \mathrm{kg})$ and arils $(0.1 \mathrm{mg} / \mathrm{kg})($ Table 1$)$. Fortunately, the level of antinutritional factor (tannin) in the aril is not a limiting factor in the utilization or consumption. Anti-nutritional factor -tannin was at low levels that would not cause any nutritional disorder in human as compared with $0.14 \mathrm{mg} \mathrm{g}^{-1}$ in African pear (Nwanna, et al., 2008).

This supports Anamayi et al., (2005) that maintained that some species like Parkia bigiobasa fruits are collected from wild and farmlands for household consumption and sales.

The contribution of forest foods to the diet varies considerably from one ecological zone to another. Throughout Nigeria, however, they supplement staple foods and are consumed during seasonal food shortages when agricultural crop supplies dwindle (Afolabi, 2008). Forest foods, especially leaves and nuts, supplement rural diets by contributing to sauces that accompany carbohydrate staples. Some forest fruits are often consumed throughout the as snacks. They also supply buffer food sources during emergency periods (Okigbo, 1986).

This species is an agro-forestry tree grown in rural part of the Rivers State which provides income and as an unconventional source of food forest products to the growers and others.

\section{SUMMARY AND CONCLUSION}

This expository work is unique and unrivaled as the species both the aril and seed contain some key dietary minerals that not only relish but will improve mineral intake from nature that can be used as supplements to replace some vital minerals of the body. Though, the little information on the documented uses of the species, observation in the rural areas showed that it is used as fuel wood, stacking yams, building and thatch houses not even any part of the tree is wasted as even the leaves are used as organic manure for domestic trees within. The consumption of the species is recommended to everybody because of its rich nutritive composition. The amino acids profile of both the seeds and edible arils should be studied in order to put the seeds which hitherto being a waste. Species could a raw material in the food and pharmaceutical industries. The economic benefit and many more insights into further intrigues of the species should be studied.

\section{REFERENCE}

Afolabi, A. A. (2008). Contributions of forest and forest products to millennium development goals. In: Onyekwelu, J. C., Adekunle, V. A. J. and Oke, D. O. (eds.). Proceedings of the $1^{\text {st }}$ National Conference of the Forests and Forest Products Society of Nigeria (FFPN) held at the Federal University of Technology, Akure, Ondo State between16th $-18^{\text {th }}$ April, 2008. P 40.

Anamayi, S. E., Anamayi, R. M., Bamikole, J. A. and Thomas, T. (2005). Contribution of locust bean fruit to household food security and poverty alleviation among rural dwellers of Igabi Local Government Area of Kaduna State. In: Popoola, L., Mfon, P. and Oni, P. I. (eds.). Proceeding of $30^{\text {th }}$ Annual Conference of FAN held in Kaduna, Kaduna State, Nigeria held between $7^{\text {th }}$ and $11^{\text {th }}$ November, 2005. Pp 325-334.

AOAC, Association of Official Analytical Chemists, (1990). In Kenneth, $H$. (eds), Official Methods of Analysis, $15^{\text {th }}$ edn. AOAC, Arlington, VA, USA. P 1298.

George, D. and Pamplona-Roger, M.D. (2010). Healthy Foods. Editorial safeliz. P 346.

Jimoh, S. O. and Haruna, E.A. (2007). Contribution of nontimber forest products to household food security and income around Onigabari forest reserve in Oyo state, Nigeria. Journal of Environmental Extension 6: 34-37.

Keay, R. W. J. Onochie, C. F. A. and Stanfield, D. P. (1964). Nigerian Trees. National Press Limited. Vol. 1. P 219.

Ogbonna, Samuel Chigbondu (1983). Some chemical components of some woody Species. Unpublished M.Sc. Thesis, Faculty of Agriculture and Forestry, University of Ibadan. P 2

Okigbo, G. (1986). Indigenous Nigerian Food Plants. Journal of West African Science Association. 6: Pp 117-121

Oregbeme, A. O. (2005). Propagation and cultivation of economic non-timber forest and fruit trees a possibility for poverty alleviation in rural communities in Edo State. In: Orheuata, A. M., Nwokoro, S. O., Ajayi, M.T ., Adekunle, A. T. and Asumugha, G. N. (ed.) Proceedings of the $39^{\text {th }}$ Annual Conference of the Agricultural Society of Nigeria held at the University of Benin City, Edo State between October 9 and 13, 2005. Pp 242-245.

Tehoundjan, Z.,Kenyue, J. and Leakey, R.R. B (2002). Domestication of Dacryodes edulis: State of the art. Forests, Trees and Livelihoods 12:3-13. 